\title{
A new method for live-trapping shrews
}

\author{
Warren S. T. HAYS*
}

Hays W. S. T. 1998. A new method for live-trapping shrews. Acta Theriologica 43: $333-335$.

A modification of the Sherman trap, intended for live-trapping of shrews (Soricidae), is presented. This trap requires only daily checks, in contrast to the two- to four-hourly checks required by other traps. A population study using the new trap design yielded 711 captures over 7520 trap-days, with $1 \%$ mortality.

Museum of Vertebrate Zoology, University of California at Berkeley, Berkeley CA 94720, USA

Key words: shrew, population, live trap

\section{Introduction}

Although shrew (family Soricidae) populations are common throughout North America, Eurasia and other regions of the world (Nowak 1991), only a few species have been subjects of intensive study. This is largely due to their extreme metabolic and thermal requirements (Vogel 1980, Genoud 1988, McNab 1991), which often make them intolerant of standard live-trapping regimens.

Most population studies reported to date have used small Sherman or Longworth traps, depending on frequent monitoring to keep mortality rates low (eg, Buckner 1966, Croin Michielsen 1966, Hawes 1977, Churchfield et al. 1995). Traps must typically by checked every 2 to 4 hours, making these studies extremely labor-intensive, and accordingly rare.

\section{Methods}

I developed a modification of the $20 \mathrm{~cm}$ Sherman trap specifically for shrews, which requires monitoring only once a day, at least during non-breeding months. Using this trap design, a population study was performed on ornate shrews Sorex ornatus (Merriam, 1895), over an 8 month period in a grassland-saltmarsh ecotone (W. S. T. Hays, in prep.).

The trap (Fig. 1) is prepared with a $20 \mathrm{~cm}$ Sherman live-trap inserted into the side of a $3.6 \mathrm{dm}^{3}$ Nalgene plastic jar (25 cm high, $15 \mathrm{~cm}$ diameter). The rear of the trap is left open, and inserted through a cut hole in the side of the jar, just large enough to admit the trap, about $3 \mathrm{~cm}$ above the

\footnotetext{
*Present address: Department of Biology, Hawaii Pacific University, Honolulu HI 96813, USA, e-mail: whays@hpu.edu
} 


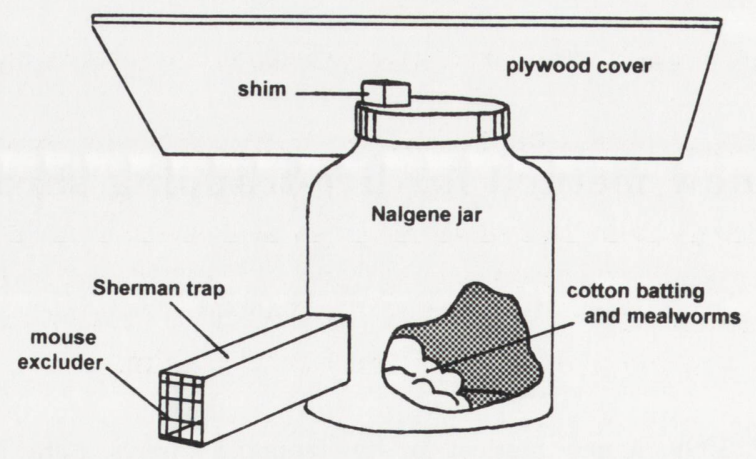

Fig. 1. A modification of the Sherman trap for live-trapping shrews.

jar's base (to prevent ground water from entering). The jar lid is ventilated, and the jar stocked with wads of cotton batting and a supply of food. A $40 \times 40 \mathrm{~cm}$ sheet of light plywood is placed on top of the jar for protection against the elements, with a shim between the board and the lid to allow ventilation.

The trap entrance is covered with $12 \mathrm{~mm}$ wire mesh, to exclude mice. The trap is intended to close after a single shrew has entered. As always when trapping such small mammals, the door mechanism must be set as lightly as possible by adjusting the trigger catch. I have also tried using Longworth traps, but have found them ineffective for very small shrews, presumably because the animals are able to crawl under the trigger bar.

Initially, mealworms, cat food, tuna, and peanut butter were tested as bait. Mealworms were chosen. In the study on $S$. ornatus, 40 large mealworms were used per trap. This amount of food (about $8 \mathrm{~g}$ ) is appropriate for this particular shrew (body weight: 2.9 to $9.2 \mathrm{~g}$ ), and can be adjusted for other shrew species. Though water was not provided in the traps used in this study, it may be necessary to add a bowl or bottle of fresh water for some shrew species.

\section{Results and discussion}

During 7520 trap-days, 711 captures were made of 161 individual shrews (captures per trap-day $=9.5 \%$ ). Trap mortality rate was only $1 \%$ of captures $(7$ shrews). However, it should be noted that during the breeding season, holding a lactating female in a trap for more than a few hours is likely to destroy her offspring.

Mealworms were found to be ideal bait. More odoriferous baits, such as cat food, tuna, and peanut butter, did not substantially increase capture rate and often caused traps to be damaged by larger animals. These baits also failed to supply the shrews with an appropriate food source, and/or had to be replaced daily due to spoilage. Mealworms survived in the field for about a month, without any tending. Mealworms for this study were cultured in boxes stocked with grain meal, so that their cost was very low.

The mouse excluder made of $12 \mathrm{~mm}$ wire mesh seems to admit shrews and exclude mice as effectively as a metal plate with a hole, recommended by Crowcroft 
(1957). On several occasions I have seen shrews run at full speed through this mesh without collision.

The completed trap in the field presents captured animals with a dry, shaded, ventilated space containing bedding and sufficient food for 24 hours. The additional expense of these traps over that of standard Shermans is less than US $\$ 1$ per trap, and initial setting time is increased by about 30 seconds per trap (not counting the time required beforehand to amass the necessary materials). Once set, little or no maintenance is required during daily trap checks.

\section{References}

Buckner C. H. 1966. Metabolism, food capacity and feeding behavior in four species of shrew. Canadian Journal of Zoology 42: 259-270.

Churchfield S., Hollier J. and Brown V. K. 1995. Population dynamics and survivorship patterns in the common shrew Sorex araneus in southern England. Acta Theriologica 40: 53-68.

Croin Michielsen N. 1966. Intraspecific and interspecific competition in the shrews Sorex araneus L. and Sorex minutus L. Archives Neerlandaises de Zoologie 17: 73-149.

Crowcroft P. 1957. The life of the shrew. Max Reinhardt, London: 1-166.

Genoud M. 1988. Energetic strategies of shrews: ecological constraints and evolutionary implications. Mammal Review 18: 173-193.

Hawes M. L. 1977. Home range, territoriality and ecological separation in sympatric shrews, Sorex vagrans and Sorex obscurus. Journal of Mammalogy 58: 354-365.

McNab B. K. 1991. The energy expenditure of shrews. [In: The biology of the Soricidae. J. S. Findley and T. S. Yates, eds]. The Museum of Southwestern Biology, University of New Mexico, Albuquerque: $35-45$.

Nowak R. M. 1991. Walker's mammals of the world. 5th ed. Johns Hopkins University Press, Baltimore: 1-1629.

Vogel P. 1980. Metabolic levels and biological strategies in shrews. [In: Comparative Physiology, Primitive Mammals. K. Schmidt-Nielsen, L. Bolis and C. R. Taylor, eds]. Cambridge University Press, Cambridge: $170-180$.

Received 7 November 1997, accepted 27 March 1998. 